Article

\title{
Development of Immediate Release Tablets Containing Calcium Lactate Synthetized from Black Sea Mussel Shells
}

\author{
Magdalena Mititelu 1,+(D), Elena Moroșan ${ }^{1,+}$, Anca Cecilia Nicoară ${ }^{2,+}$, Ana Andreea Secăreanu ${ }^{2,+}$, Adina

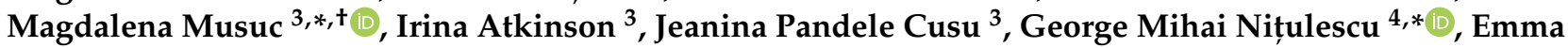 \\ Adriana Ozon $^{2, *}$, Iulian Sarbu ${ }^{5, *(D)}$ and Teodora Dalila Balaci ${ }^{2}$
}

Citation: Mititelu, M.; Moroșan, E.; Nicoară, A.C.; Secăreanu, A.A.;

Musuc, A.M.; Atkinson, I.; Pandele Cusu, J.; Nițulescu, G.M.; Ozon, E.A.; Sarbu, I.; et al. Development of Immediate Release Tablets Containing Calcium Lactate Synthetized from Black Sea Mussel Shells. Mar. Drugs 2022, 20, 45. https://doi.org/10.3390/md20010045

Academic Editor: Alexander N. Shikov

Received: 11 December 2021 Accepted: 31 December 2021 Published: 2 January 2022

Publisher's Note: MDPI stays neutral with regard to jurisdictional claims in published maps and institutional affiliations.

Copyright: (C) 2022 by the authors. Licensee MDPI, Basel, Switzerland. This article is an open access article distributed under the terms and conditions of the Creative Commons Attribution (CC BY) license (https:// creativecommons.org/licenses/by/ $4.0 /)$
1 Department of Clinical Laboratory and Food Safety, Faculty of Pharmacy, Carol Davila University of Medicine and Pharmacy, 6 Traian Vuia Street, 020945 Bucharest, Romania; magdalena.mititelu@umfcd.ro (M.M.); elena.morosan@umfcd.ro (E.M.)

2 Department of Pharmaceutical Technology and Biopharmacy, Faculty of Pharmacy, Carol Davila University of Medicine and Pharmacy, 6 Traian Vuia Street, 020945 Bucharest, Romania; anca.nicoara@umfcd.ro (A.C.N.); ana.stanescu@umfcd.ro (A.A.S.); teodora.balaci@umfcd.ro (T.D.B.)

3 "Ilie Murgulescu" Institute of Physical Chemistry, 202 Spl. Independentei, 060021 Bucharest, Romania; iatkinson@icf.ro (I.A.); jeanina@icf.ro (J.P.C.)

4 Department of Pharmaceutical Chemistry, Faculty of Pharmacy, Carol Davila University of Medicine and Pharmacy, 6 Traian Vuia Street, 020945 Bucharest, Romania

5 Department of Pharmaceutical Physics and Biophysics, Drug Industry and Pharmaceutical Biotechnologies, Faculty of Pharmacy, "Titu Maiorescu" University, 004051 Bucharest, Romania

* Correspondence: amusuc@icf.ro (A.M.M.); george.nitulescu@umfcd.ro (G.M.N.); emma.budura@umfcd.ro (E.A.O.); iulian.sarbu@prof.utm.ro (I.S.)

+ These authors contributed equally to this work.

\begin{abstract}
Nowadays, the use of marine by-products as precursor materials has gained great interest in the extraction and production of chemical compounds with suitable properties and possible pharmaceutical applications. The present paper presents the development of a new immediate release tablet containing calcium lactate obtained from Black Sea mussel shells. Compared with other calcium salts, calcium lactate has good solubility and bioavailability. In the pharmaceutical preparations, calcium lactate was extensively utilized as a calcium source for preventing and treating calcium deficiencies. The physical and chemical characteristics of synthesized calcium lactate were evaluated using Fourier Transform Infrared Spectroscopy, X-ray diffraction analysis and thermal analysis. Further, the various pharmacotechnical properties of the calcium lactate obtained from mussel shells were determined in comparison with an industrial used direct compressible Calcium lactate DC (PURACAL $\left.{ }^{\circledR}\right)$. The obtained results suggest that mussel shell by-products are suitable for the development of chemical compounds with potential applications in the pharmaceutical domain.
\end{abstract}

Keywords: calcium lactate; mussel shells; physical-chemical characterization; preformulation studies

\section{Introduction}

The huge growing demand for renewable feedstocks makes marine byproducts one of the most attractive research areas. The transformation of marine-sourced biomass into chemical compounds has attracted attention for the development of renewable compounds. Considering the enormous amount of water sources (around 70\% from the planet's surface), the aquaculture industries become a valuable source of biochemical compounds [1-6]. Mussels, a high protein food source, were produced using around $95 \%$ from aquaculture methods in the total world mollusk production in 2013 [1]. The exoskeletons of mollusks, such as snails, mussels, oysters are composed mostly (over $90 \%$ ) of calcium carbonate mixed with a small amount of protein material that gives the carcass strength. Mollusks are of general importance in food chains and as members of ecosystems. Certain species are of direct or indirect commercial and even medical importance to humans. Many mollusks 
are a source of food for many crops, and therefore, play an important role in the fishing industries of many countries, especially in Asian countries, such as China and Japan. Many species of shellfish are also used to make ornaments and are harvested for the pearl and mother-of-pearl industries [7-9].

World aquaculture production (fish, seafood and aquatic plants) reached a historical record in 2018 of 114.5 million tons of live mass. The main producing countries are China, India, Indonesia, Vietnam, Bangladesh, Egypt, Norway and Chile. In recent years, bivalve culture has expanded considerably, China is the largest consumer and producer of mollusks, accounting for about $84 \%$ of the global volume grown in 2017. Byproducts resulting from mollusk culture can be used in a variety of industrial products, such as fertilizers, building materials, poultry feed, pharmaceuticals and nutraceuticals [10,11].

One of the possibilities of capitalizing on the waste resulting from the food recovery of mollusks consists in capitalizing on the calcium in the shells. Until now, there are few studies on the cleaning process of the mussel shells in order to obtain calcium carbonate and subsequently, calcium lactate [12-14].

Calcium is among the most important mineral from the human body (an adult organism contains $1200 \mathrm{~g}$ of calcium) [15]. From the whole quantity of calcium, $99 \%$ is presented in teeth and bones and the rest of $1 \%$ from cell sap has an important role in muscle contraction, cellular metabolism, neural transmission, etc. [16]. One of the most important sources of calcium is calcium lactate pentahydrate. Compared with other calcium salts, calcium lactate has great bioavailability and good solubility. Calcium lactate is a nontoxic and water-soluble compound used as calcium supplement [17], anti-microbial [18], anti-carcinogen [19], etc.

The present study developed a way to capitalize on calcium from mussel shells in the form of obtaining calcium lactate for pharmaceutical use. Two species of mussels Mytilus galloprovincialis and Mytilus edulis are found in abundance in the Black Sea. By processing the mussel shells on the Romanian Black Sea coast (Figure 1), calcium lactate of pharmaceutical purity was obtained [20].

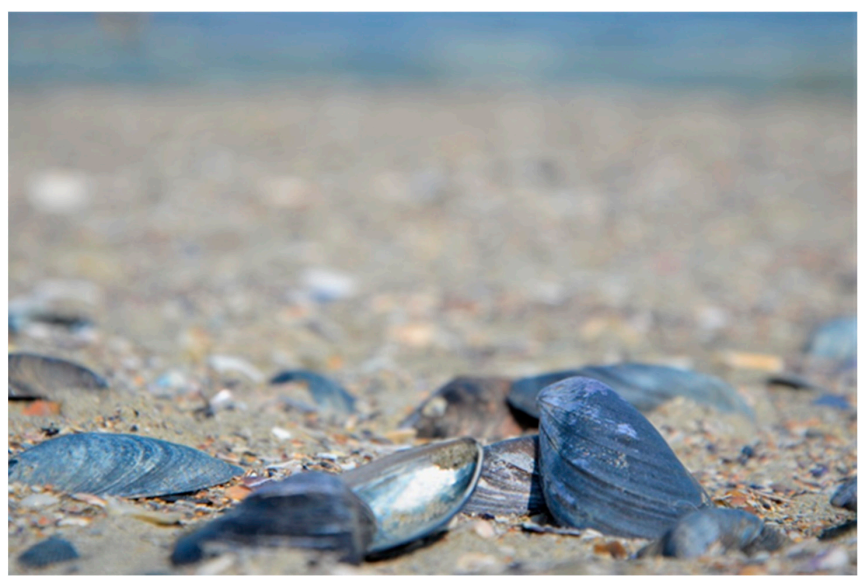

Figure 1. Mussel shells from Romanian Black Sea coast.

\section{Results and Discussion}

\subsection{Elemental Analysis}

The results of the elemental analysis are presented in Table 1.

Table 1. Elemental analysis of the obtained calcium lactate.

\begin{tabular}{ccccc}
\hline & $\mathbf{C} \%$ & $\mathbf{H} \%$ & $\mathbf{N} \%$ & $\mathbf{S} \%$ \\
\hline Assay values & $30.69 \pm 0.40$ & $4.87 \pm 0.30$ & $1.73 \pm 0.40$ & $0.34 \pm 0.05$ \\
$\begin{array}{c}\text { (Synthesized calcium lactate) } \\
\text { Theoretical values }\end{array}$ & 33.02 & 4.62 & 0.00 & 0.00 \\
\hline
\end{tabular}


Based on the carbon content of the sample of $30.69 \pm 0.4 \%$ and reported to the expected theoretical content of $33.02 \%$, the content of calcium lactate in the sample was calculated as $92.94 \pm 1.21 \%$. The presence of nitrogen in the sample indicates the possibility of the existence of another calcium salt, most probably of calcium nitrate. Figure 2 represents the elemental composition of the two compounds: calcium lactate and calcium nitrate.<smiles>CO[N+](=O)[O-]</smiles>

Exact Mass : $163.938 \mathrm{~g} / \mathrm{mol}$ Formula : $\mathrm{CaN}_{2} \mathrm{O}_{6}$

Composition : N $17.07 \%$ O $58.50 \%$ Ca $24.42 \%$<smiles>CC(O)C(=O)[O-]</smiles>

Exact Mass : $218.010 \mathrm{~g} / \mathrm{mol}$

Formula : $\mathrm{C}_{6} \mathrm{H}_{10} \mathrm{CaO}_{6}$

Composition : C $33.02 \%$ H $4.62 \%$ O $43.99 \%$ Ca $18.37 \%$

Figure 2. Elemental composition of calcium lactate and calcium nitrate.

Based on the nitrogen content of $1.73 \pm 0.4 \%$ from the sample and reported to the expected theoretical content of $17.07 \%$, the content of calcium nitrate in the sample was calculated as $10.13 \pm 2.34 \%$. The analysis indicates that the sample contains $92.94 \pm 1.21 \%$ calcium lactate and $10.13 \pm 2.34 \%$ calcium nitrate. Based on this composition, the average content in calcium is $18.96 \pm 0.11 \%$.

According to the elemental quantification, in order to obtain $65 \mathrm{mg}$ calcium ion concentration per tablet, $342.1052 \mathrm{mg}$ of calcium lactate must be included in one dose.

\subsection{Fourier-Transform Infrared Spectroscopy (FTIR)}

FTIR spectra of synthesized calcium lactate and standard calcium lactate are shown in Figure 3.

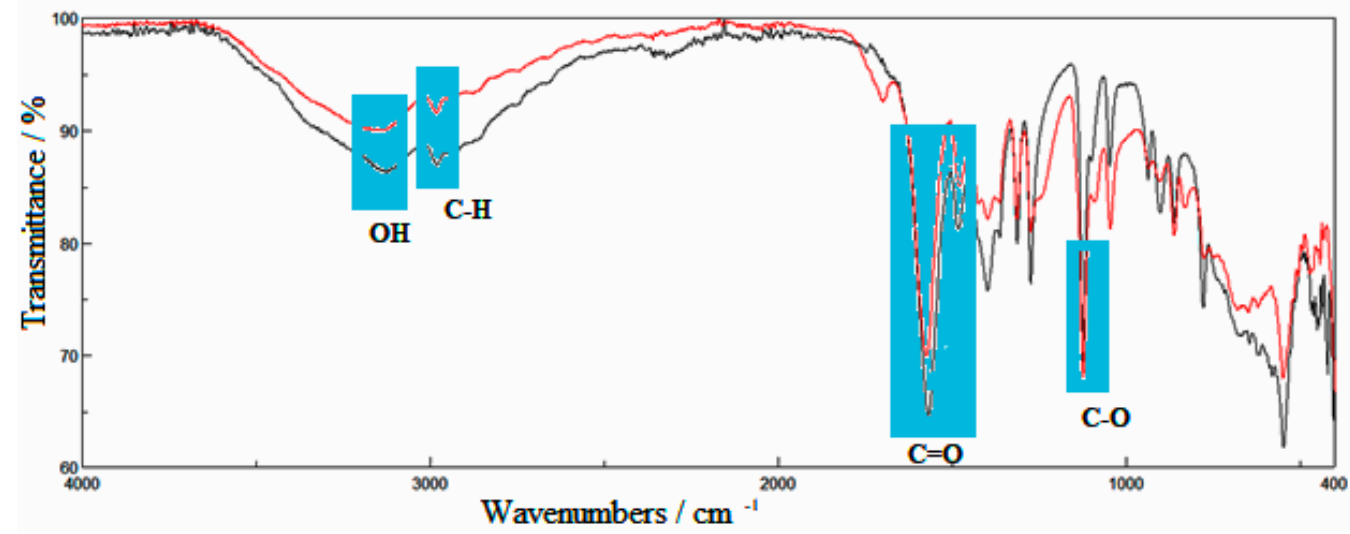

Figure 3. FTIR spectra of synthesized calcium lactate (red line) and standard calcium lactate (black line).

From Figure 3 it was observed that the carboxylate group has a large dipole moment and gives two intense peaks, assigned as the asymmetric stretch band registered at $1573.6 \mathrm{~cm}^{-1}$ and $1478.2 \mathrm{~cm}^{-1}$. The large band at $3157.9 \mathrm{~cm}^{-1}$ is produced by the hydroxyl group, while the strong band observed at $1123.3 \mathrm{~cm}^{-1}$ is produced by the C-O bond stretching. The band at $2982.4 \mathrm{~cm}^{-1}$ is assigned to the C-H bond stretch [21,22].

The FTIR spectra of both types of calcium lactate, synthesized and standard, are very similar as can be observed in Figure 3. The Pearson correlation between the two sets of spectral data is 0.953 . The small band observed at $1698.0 \mathrm{~cm}^{-1}$ is produced by the small content of calcium nitrate from the composition of the newly synthesized calcium lactate. This band is not visible in the spectrum of the standard calcium lactate. 


\subsection{X-ray Diffraction}

The X-ray diffraction (XRD) pattern of synthesized calcium lactate is represented in Figure 4. In Table 2 the peak angles, $\mathrm{d}$-values, and heights for calcium lactate pentahydrate are given according to the reference card PDF card number 00-029-1596 for calcium lactate pentahydrate [23]. The XRD patterns refinement using the Whole Pattern Powder Fitting (WPPF) method confirmed the presence of only the calcium lactate as a single crystalline phase. No other calcium phases were presented. The XRD analysis does not reveal the presence of calcium nitrate may be due to its small quantity in the prepared sample.

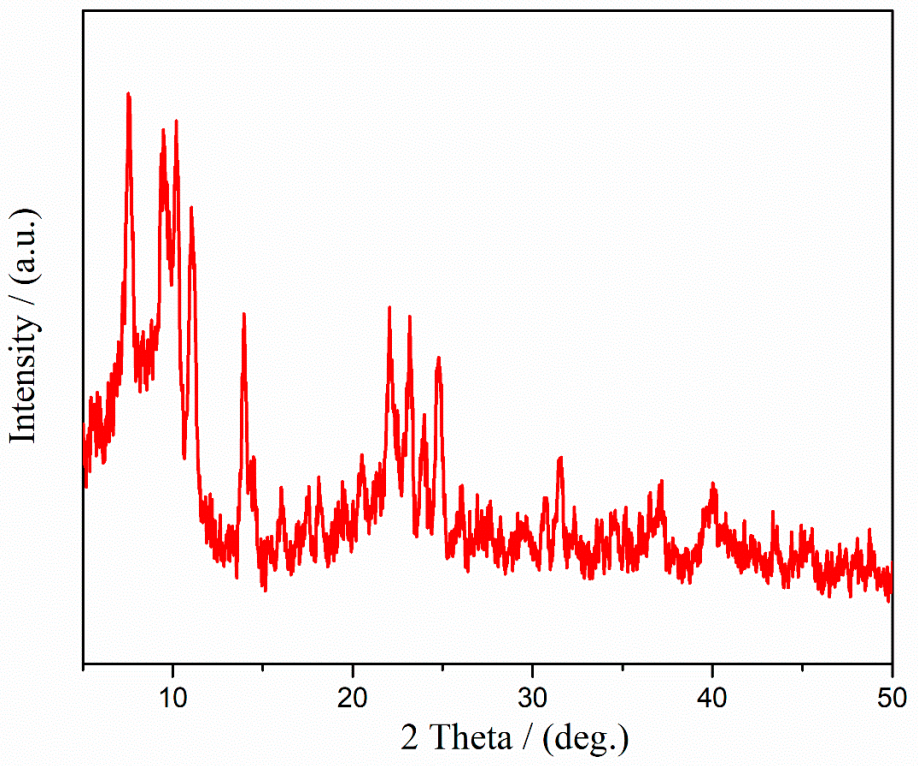

Figure 4. XRD spectrum of synthesized calcium lactate.

Table 2. Tabulated peak angles, d-values, and heights for calcium lactate pentahydrate. In parenthesis are given one standard deviation of the least units cited (PDF card number 00-029-1596).

\begin{tabular}{ccc}
\hline 2 Theta (deg) & $\mathbf{d}(\mathbf{A})$ & Height (cps) \\
\hline $7.53(3)$ & $11.73(4)$ & $136(15)$ \\
$9.49(9)$ & $9.31(9)$ & $115(14)$ \\
$10.28(3)$ & $8.60(2)$ & $137(15)$ \\
$11.09(3)$ & $7.97(2)$ & $124(14)$ \\
$13.98(4)$ & $6.33(17)$ & $94(13)$ \\
$14.3(4)$ & $6.17(6)$ & $27.66(4)$ \\
$16.02(7)$ & $5.53(2)$ & $25(6)$ \\
$17.56(2)$ & $5.047(5)$ & $25(6)$ \\
$18.22(7)$ & $4.89(2)$ & $25(6)$ \\
$20.49(9)$ & $4.31(7)$ & $14(5)$ \\
$22.20(3)$ & $4.00(5)$ & $56(10)$ \\
$23.20(4)$ & $3.831(6)$ & $81(12)$ \\
$23.86(3)$ & $3.726(5)$ & $51(9)$ \\
$24.75(3)$ & $3.726(5)$ & $80(12)$ \\
$30.74(9)$ & $2.906(8)$ & $19(3)$ \\
$31.56(6)$ & $2.832(5)$ & $38(8)$ \\
$37.12(8)$ & $2.420(5)$ & $28(7)$ \\
$39.99(7)$ & $2.253(4)$ & $27(7)$ \\
$43.4(2)$ & $2.082(10)$ & $10(4)$ \\
\hline
\end{tabular}

\subsection{Thermal Analysis}

The thermal curves (TGA-DTA-DTG) of the synthesized calcium lactate are shown in Figure 5. As reported in the literature, four mass loss steps are included in the thermal 
decomposition of calcium lactate pentahydrate $[24,25]$. The first weight loss step is in two stages: one between 30 and $120{ }^{\circ} \mathrm{C}\left(T_{\text {DTA }}=51.58{ }^{\circ} \mathrm{C} / 78.83{ }^{\circ} \mathrm{C}, T_{\text {DTG }}=72.75{ }^{\circ} \mathrm{C} / 82.66{ }^{\circ} \mathrm{C}\right)$ and another one between 120 and $200{ }^{\circ} \mathrm{C}$ attributed to water molecules from calcium lactate. The TG data agree with the XRD pattern which demonstrates the presence of calcium lactate pentahydrate. The total weight loss for the first step in the temperature range $30-200{ }^{\circ} \mathrm{C}$ $\left(T_{\text {DTG }}=147.16^{\circ} \mathrm{C}\right)$ corresponds to $23.29 \%$. The second weight loss which appears in the temperature range between $200-373{ }^{\circ} \mathrm{C}\left(T_{\text {DTG }}=281.25^{\circ} \mathrm{C}\right)$ corresponds to $18.71 \%$ of mass loss. The third step between $372-533{ }^{\circ} \mathrm{C}$ temperature range $\left(T_{\mathrm{DTA}}=393{ }^{\circ} \mathrm{C} / 422.7{ }^{\circ} \mathrm{C}\right.$, $T_{\text {DTG }}=385.83{ }^{\circ} \mathrm{C} / 420.83{ }^{\circ} \mathrm{C}$ ) corresponds to a $25.66 \%$ weight loss. These two steps are associated with the formation of calcium carbonate [24,25]. The final step between 533$865^{\circ} \mathrm{C}\left(T_{\mathrm{DTA}}=680^{\circ} \mathrm{C}, \mathrm{T}_{\mathrm{DTG}}=657.1^{\circ} \mathrm{C}\right)$ temperature range corresponds to a $15.4 \%$ weight loss. The final residue is $17.04 \%$ and is represented by calcium oxide. Calcium oxide was formed in a process known as calcination where calcium carbonate loses carbon dioxide through thermal decomposition [25].

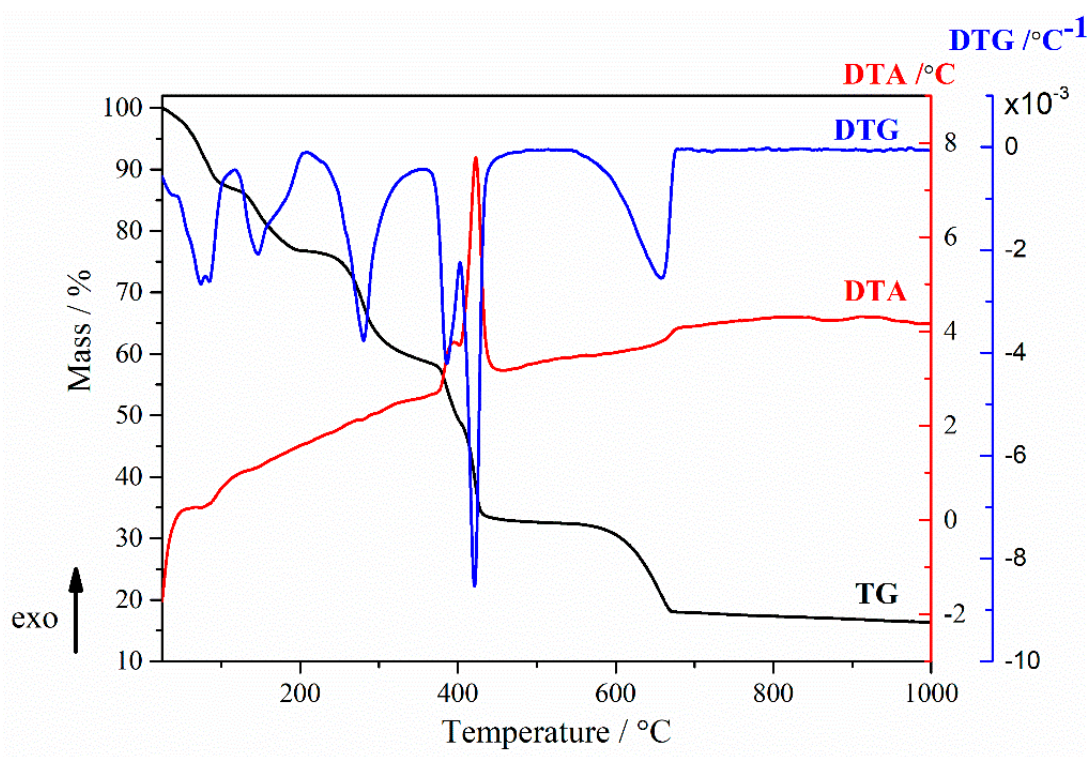

Figure 5. TG/DTA curves of synthesized calcium lactate.

\subsection{Calcium Lactate Pharmacotechnical Properties}

Before including a new ingredient in the tablet's formulation, the pharmacotechnical properties must be determined to establish a correct formulation and to choose the suitable manufacturing method, which leads to a quality final product with satisfactory and predictable characteristics.

The aim is to manufacture the tablets by direct compression technology, this being usually the most desirable method, due to its well-known advantages, especially the lack of moisture needs and the high protection of the active ingredient.

To perform an objective and accurate analysis of the studied calcium lactate characteristics, all pharmacotechnical properties were determined in comparison with an already industrial used direct compressible (DC) sort, Calcium lactate DC (PURACAL ${ }^{\circledR}$ ) synthetized by PURAC, Netherlands. The pharmacotehnical parameters determined for both tested calcium lactate powders are reported in Table 3. 
Table 3. Pharmacotechnical properties for calcium lactate powders.

\begin{tabular}{ccc}
\hline Parameter & $\begin{array}{c}\text { Calcium Lactate Synthetized } \\
\text { from Mussels }\end{array}$ & $\begin{array}{c}\text { Calcium Lactate DC } \\
\text { (PURACAL }\end{array}$ \\
\hline Moisture content $(\%)$ & $8.60 \pm 0.44$ & $18.70 \pm 0.81$ \\
Flow time $(\mathrm{s}){ }^{*}$ & $25.2 \pm 0.79$ & $6.44 \pm 0.33$ \\
Angle of repose $\left(\theta^{\circ}\right)^{*}$ & $32.7 \pm 0.58$ & $26.22 \pm 0.49$ \\
Flow rate $(\mathrm{g} / \mathrm{s})^{*}$ & 2.381 & 9.316 \\
$\mathrm{~V}_{0}(\mathrm{~mL})$ & $59.9 \pm 0.18$ & $86.2 \pm 0.12$ \\
$\mathrm{~V}_{500}(\mathrm{~mL})$ & $53 \pm 0.23$ & $75.7 \pm 0.19$ \\
$\mathrm{~V}_{1250}(\mathrm{~mL})$ & $52.8 \pm 0.08$ & $75.5 \pm 0.06$ \\
Bulk density $(\mathrm{g} / \mathrm{mL})$ & 0.834 & 0.580 \\
Tapped density $(\mathrm{g} / \mathrm{mL})$ & 0.947 & 0.662 \\
Hausner's ratio $(\mathrm{HR})$ & 1.13 & 1.14 \\
Carr Index $(\mathrm{CI})(\%)$ & 11.93 & 12.38 \\
\hline
\end{tabular}

* nozzle: $15 \mathrm{~mm}$, no stirring.

The calcium lactate synthetized from mussels presented a surprisingly lower content in moisture $(8.6 \%)$ than the processed DC powder $(18.7 \%)$, this being a suitable characteristic for the ingredients used in direct compression.

For both powders, the flowability parameters could not be registered using the $10 \mathrm{~mm}$ nozzle, as they were not consistently flowing. When changing with a $15 \mathrm{~mm}$ nozzle, they both presented as free-flowing, with no stirring being necessary. In contrast with the results on the loss of drying, the flowability was better for PURACAL ${ }^{\circledR}$, which had a flowing time of $6.44 \mathrm{~s}$, an angle of repose around $26^{\circ}$ and the flowing rate was $9.316 \mathrm{~g} / \mathrm{s}$. The obtained values are showing that the powder has a good free flow, ideal for manufacturing tablets by direct compression technology. For calcium lactate synthetized from mussels, the flowing time was $25.2 \mathrm{~s}$, with an angle of repose around $32^{\circ}$ and a flowing rate of $2.381 \mathrm{~g} / \mathrm{s}$, typical behavior for powders with poor free flow. Considering that the flowing was possible without stirring and through a medium diameter nozzle, the results are estimated to be acceptable and must be considered when formulating the tablets. Still, the calcium lactate synthetized from mussels demonstrated a notable flowability in comparison with most of the pharmaceutical ingredients obtained from natural sources.

The volumetric characteristics also provide useful information and unexpected results. Even the bulk and tapped densities had different values, with a much higher density for the calcium lactate synthetized from mussels, the decreases in volumes after 500 and 1250 tapping were similar, leading to close values for HR and IC. Both materials showed a good flow (1.13 and 1.14 for HR) and very good compressibility (11.93 and 12.38 for IC), but it can be affirmed that the calcium lactate synthetized from mussels displays a better ability for direct compression. The results were not at all predictable, as it is unusual for a powder with a natural origin to have superior compressibility than a material specially processed to fulfill this function [26-31].

After the particles dimensions were determined, a histogram (Figure 6) was obtained by representing the distribution of particle size on granulometric classes for both studied formulations.

From Figure 6 it can be noticed that most of the particles belonging to calcium lactate from sea mussels have a particle size between 80 and $315 \mu \mathrm{m}$, meantime in the DC calcium lactate a considerable part of the particles have larger dimensions between 160-600 $\mu \mathrm{m}$. These results well explain the flowability obtained values, as the smaller particles are flowing slowly, and the bigger ones present an excellent flow. Concerning the compressibility, it can be observed exactly the opposite, the particle diameters are justified by the significant difference in the powder's density, but the preferable compressibility was exhibited by the lower sizes particles. 


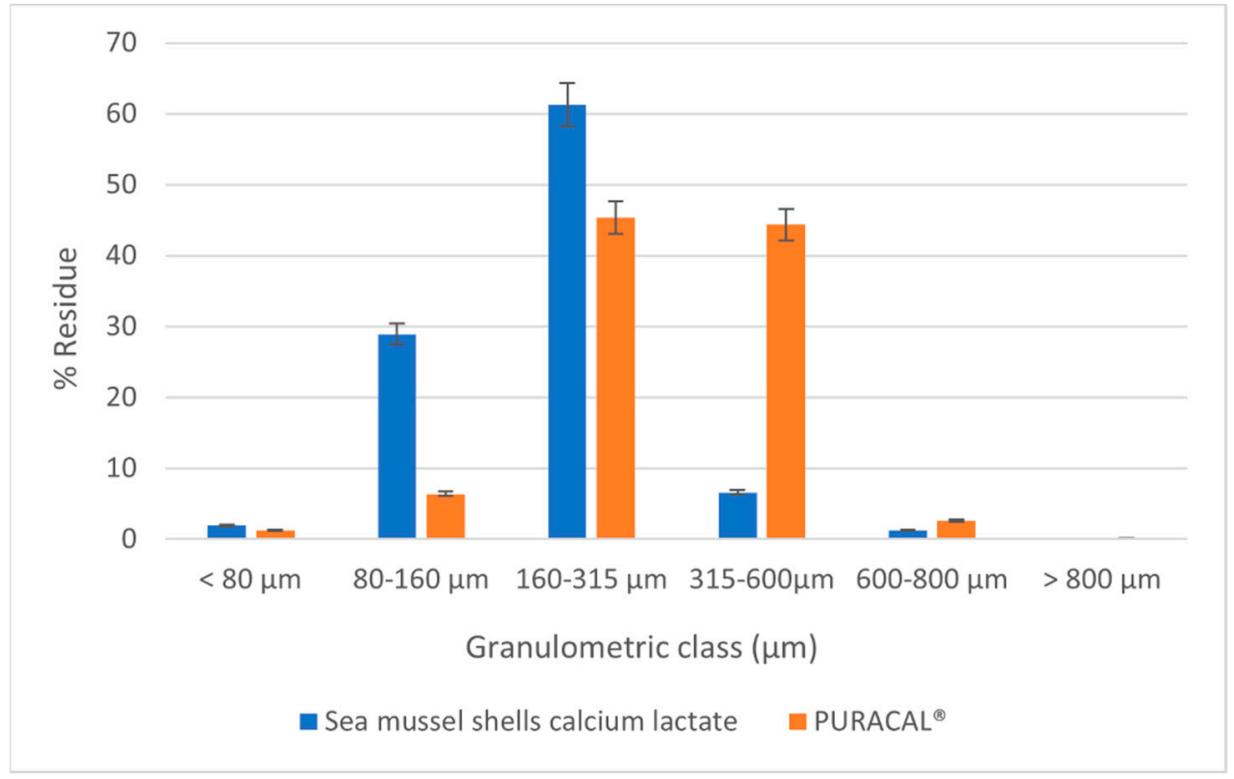

Figure 6. Granulometric analysis of calcium lactate powders.

Considering these aspects determined in the pharmacotechnical powder study, when the formulations for tablets were decided, it must select excipients with very good flowability for the calcium lactate from mussels and with higher compressibility for the DC calcium lactate $[32,33]$.

\subsection{Tablets Preformulation Studies}

Both bulk powders used for direct compression are white, fine and homogenous.

\subsection{Precompression Studies for Tablets Containing Calcium Lactate}

In order to determine the performance of the material during the direct compression and to accurately select the process parameters, different tests were performed on the powder blends. The samples were noted considering the active ingredients: F1—mussels calcium lactate and F2-DC calcium lactate.

The pharmacotechnical characteristics are presented in Table 4.

Table 4. Precompression properties for direct compression powders.

\begin{tabular}{ccc}
\hline Parameter & F1 & F2 \\
\hline Moisture content $(\%)$ & $5.20 \pm 1.28$ & $7.90 \pm 1.36$ \\
Flow time $(\mathrm{s})^{*}$ & $10.5 \pm 0.71$ & $5.68 \pm 0.58$ \\
Angle of repose $\left(\theta^{\circ}\right)^{*}$ & $24.80 \pm 0.61$ & $24.75 \pm 0.72$ \\
Flow rate $(\mathrm{g} / \mathrm{s})^{*}$ & 5.714 & 10.563 \\
$\mathrm{~V}_{0}(\mathrm{ml})$ & $73.4 \pm 0.11$ & $82.4 \pm 0.18$ \\
$\mathrm{~V}_{500}(\mathrm{ml})$ & $65.5 \pm 0.19$ & $73.6 \pm 0.14$ \\
$\mathrm{~V}_{1250}(\mathrm{ml})$ & $64.7 \pm 0.24$ & $72.8 \pm 0.11$ \\
Bulk density $(\mathrm{g} / \mathrm{mL})$ & 0.681 & 0.606 \\
Tapped density $(\mathrm{g} / \mathrm{mL})$ & 0.772 & 0.686 \\
Hausner's ratio $(\mathrm{HR})$ & 1.13 & 1.13 \\
Carr Index $(\mathrm{CI})(\%)$ & 11.78 & 11.66 \\
\hline
\end{tabular}

*nozzle: $15 \mathrm{~mm}$, no stirring.

In terms of moisture content, from Table 4 was observed a drastic decrease of the values for both active ingredients after mixing with the excipients. Humidity low values are ideal for powders processed by direct compression and this beneficial aspect was reached by selecting adequate excipients. 
Additionally, a significant improvement in the flowability of both ingredients was noticed. The increase in flow rate is more important for the mussel's calcium lactate formulation (from $2.381 \mathrm{~g} / \mathrm{s}$ to $5.714 \mathrm{~g} / \mathrm{s}$ ), as it was initially weaker. If for F1 it was doubled, for F2 the rising was not so remarkable (from $9.316 \mathrm{~g} / \mathrm{s}$ to $10.563 \mathrm{~g} / \mathrm{s}$ ). PURACAL ${ }^{\circledR}$ showed great flowability anyway, but the main purpose was to associate excipients able to enhance mussels' calcium lactate flowing performances. The determined results prove that both materials have a good flow behavior suitable for compression technology.

Concerning the compressibility, the changes are not so notable, as the characteristics of raw materials were already good enough for processing into tablets. Still, a slight improvement for both powders was remarked, with a pronounced decrease in the F1 density, advantageous for the tableting as this study was not constrained in using a high compression force [34-36].

Figure 7 represented the histogram of particle size distribution on granulometric classes for both formulations.

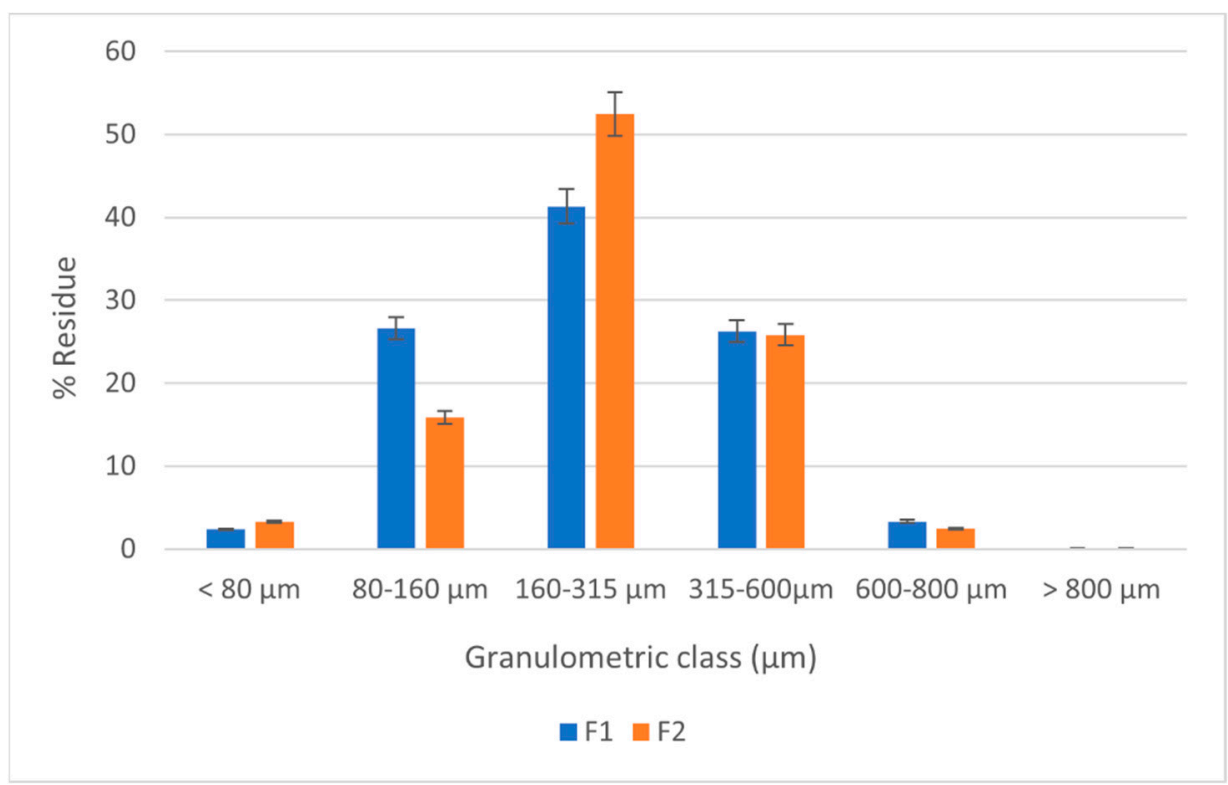

Figure 7. Granulometric analysis of the direct compression materials.

It was also observed that the particle size distribution suffered a relevant change, this directly influenced the flowability of the materials, as the specific test suggested. From Figure 7 a more homogenous distribution on the histogram was observed, with a significant increase of the dimensions, also an opportunity for the compression process.

\subsection{Quality Parameters of the Tablets}

Round shape uncoated tablets with smooth and uniform appearance, intact edges, a flat surface, white colored, were obtained for both formulations (Figure 8).

The manufactured tablets quality attributes were established by different physical and mechanical characteristics, and the results of the tests are listed in Table 5.

The average sizes of the tablets (thickness $4 \mathrm{~mm}$ and diameter $12 \mathrm{~mm}$ ) are evidence of the uniformity in the structure of the material for direct compression, good flowability and compressibility of the blend, and a well-conducted process. From Table 5 the results for both formulations comply with pharmacopeial criteria and low values for SD show the homogeneity between the tablets of the same batch. 

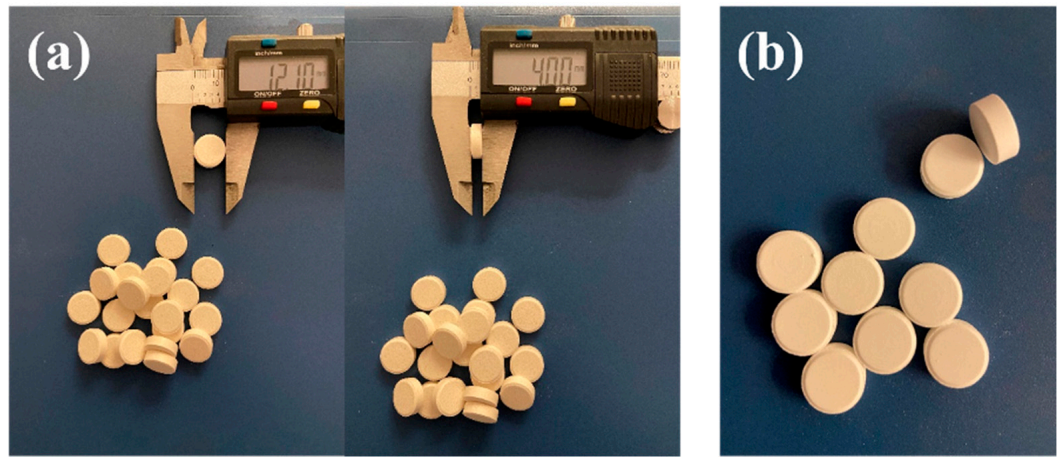

Figure 8. Calcium lactate tablets appearance (a) F1 and (b) F2.

Table 5. The pharmacotechnical and in vitro evaluation of the calcium lactate tablets.

\begin{tabular}{ccc}
\hline & \multicolumn{2}{c}{ Formulation Code } \\
\cline { 2 - 3 } Tested Parameters & F1 & F2 \\
\cline { 2 - 3 } & $4.00 \pm 0.19$ & $4.00 \pm 0.24$ \\
Thickness (mm) & $12.00 \pm 0.54$ & $12.00 \pm 0.38$ \\
Diameter (mm) & $546.00 \pm 2.43$ & $547.00 \pm 3.78$ \\
Mass uniformity & $65.10 \pm 4.65$ & $69.30 \pm 3.98$ \\
Mechanical resistance (N) & $0.18 \pm 0.25$ & $0.31 \pm 0.26$ \\
Friability (\%) & $288 \pm 2$ & $418 \pm 3$ \\
In Vitro disintegration time (seconds) & $96.77 \pm 2.85$ & $95.12 \pm 3.44$ \\
In Vitro dissolution rate, after 30 min (\%) & &
\end{tabular}

The weight variation for both formulations also conforms to the compendial standard, indicating a consistency of dosage obtained by uniform filling of the mold during the process. The results are typical for formulations with great flow properties.

Concerning the hardness and friability, some differences between formulations were observed. F1 presents a lower mechanical resistance $(65.10 \pm 4.65 \mathrm{kN})$ and, also, a lower friability $(0.18 \pm 0.25 \%)$ than F2 $(69.30 \pm 3.98 \mathrm{kN}$, respectively $0.31 \pm 0.26 \%)$. These properties were dependent on the mechanical characteristics of the excipients and on the applied compression force. The desirable hardness was around $60 \mathrm{kN}$, which ensures a proper disintegration and dissolution of the tablets. The ideal friability is $0 \%$ in order to withstand any mechanical shocks. The registered results were indicated that the tablets manufactured according to F1, the formulation containing mussels' calcium lactate, have better hardness and lower friability [37-41].

The in-vitro disintegration time was around $7 \min (418 \pm 3 \mathrm{~s})$ for F2 and below $5 \mathrm{~min}$ for F1 (288 $\pm 2 \mathrm{~s}$ ) proving the significant influence of sodium starch glycolate used as superdisintegrant excipient in the first formulation. Although both formulations are disintegrated in accordance with Pharmacopoeia requirements for immediate release tablets, it was obvious that the formulation containing mussels' calcium lactate presents a better performance. A quicker release of the active ingredient from the tablets ensures a proper absorption rate and thus it can exert its therapeutic action in the body.

The disintegration time depends on the composition of the tablets, their size and shape and their mechanical strength, which results from the application of compressive force. Disaggregation is considered to be an inverse process to that of compression.

The disintegration process involves solubility of the substance and the nature of the disintegrant, porosity and moisture of the tablet, and the hydrophilicity of the active ingredient [42,43].

F1 presented a higher dissolution rate $(96.77 \pm 2.85 \%)$ than F2 $(95.12 \pm 3.44 \%)$. Both formulations are meeting the imposed Pharmacopoeia limits for immediate release tablets, predictable for high water soluble ingredients, and for systems processed by direct compression. Still, it can be observed the important influence of choosing the right formulation in 
the development of a new pharmaceutical product and the selection of a superdisintegrant in the composition of tablets [44-49]. Our future studies are oriented on developing more tablets formulations containing mussels shell calcium lactate and registering the dissolution profiles of different media, including the digestive fluids simulating ones.

\section{Materials and Methods}

\subsection{Materials}

The raw material used for the calcium lactate synthesis consists of mussels collected from natural populations of the Romanian Black Sea coast.

All used reagents and the reference substances were of analytical purity. They were provided by Fluka ${ }^{\circledR}$ Analytical, Switzerland and Sigma-Aldrich, Germany. The excipients for tablets were purchased from different manufacturers, as follows: Microcrystalline Cellulose 302 from JRS PHARMA GmbH \& Co. KG, Rosenberg, Germany, Sodium Starch Glycolate from Maruti Chemicals, Gujarat, India, Maize Starch from HL Agro, Mumbai, India, Magnesium Stearate from Peter Greven, Netherlands and Talc from Peter Greven, Netherlands.

The weighing of the substances was performed with a Mettler Toledo AT261 balance (with $0.01 \mathrm{mg}$ sensitivity).

\subsection{Synthesis of Calcium Lactate}

The mussels were rinsed thoroughly under running water. Flesh and shells were manually separated with a knife. Out of $2.5 \mathrm{~kg}$ whole mussels, $0.3 \pm 0.05 \mathrm{~kg}$ mussel flesh and $1.2 \pm 0.2 \mathrm{~kg}$ shells were obtained.

The separated shells were carefully rinsed, dried and then ground with a colloidal ball mill, to increase the reactive surface. The powder was deproteinized using a $1 \% \mathrm{KOH}$ solution to remove the organic components and then, treated with a 30\% lactic acid solution.

The flowchart of calcium lactate production is shown in Figure 9.

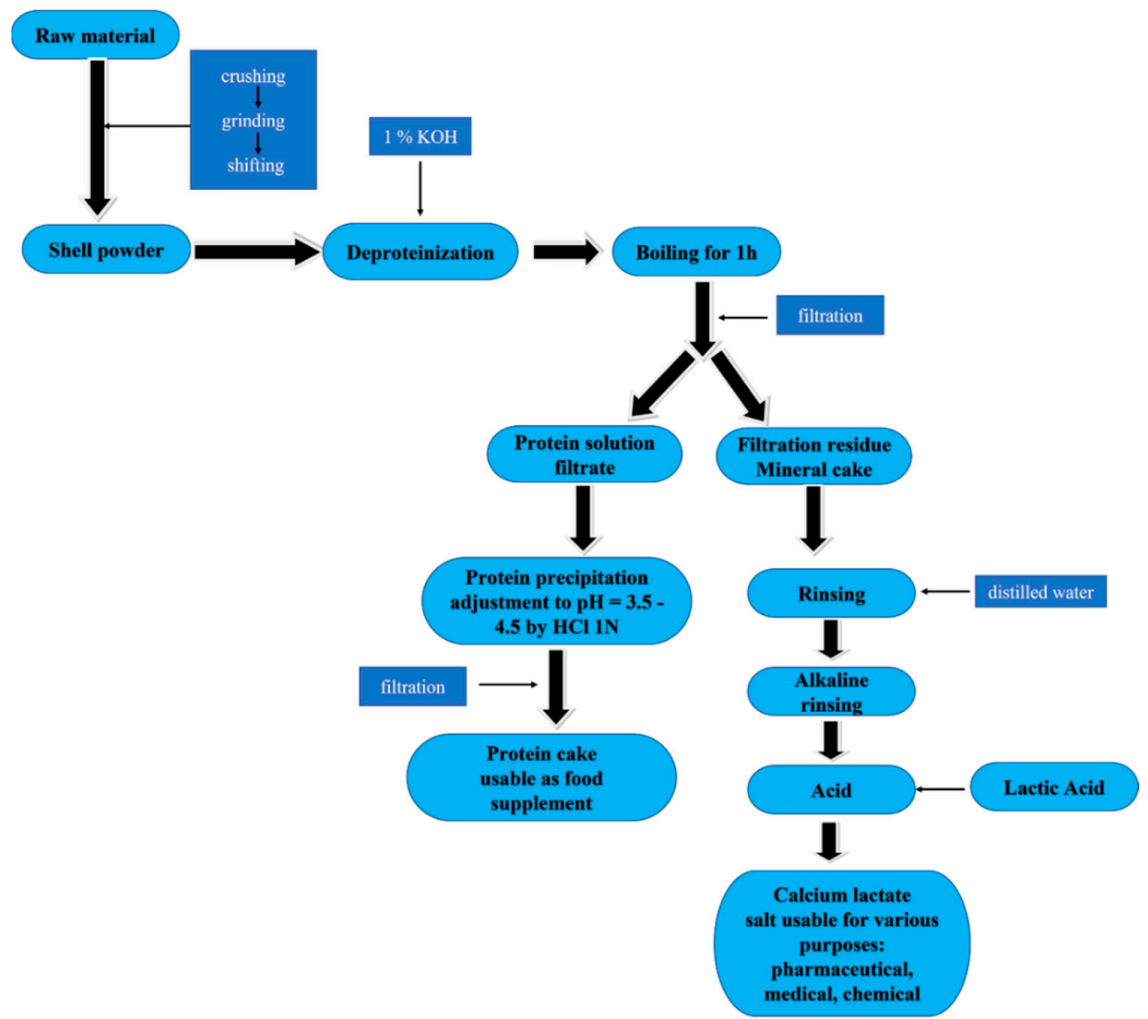

Figure 9. Flowchart for Calcium lactate technological synthesis from mussel shells. 
The salt purification is based on the difference in diethyl ether solubility between lactic acid and calcium lactate. The yield calculated on the anhydrous salt in relation to the use of $30 \%$ lactic acid was $85.62 \%$.

\subsection{Elemental Analysis}

Quantitative elemental analysis was expressed as a percentage of the quantitative ratios between the atoms of the studied organic compound. A Perkin-Elmer 2400 Series II CHNS/O was used. The samples were weighed in tin microcans using a Perkin Elmer microbalance. The combustion temperature was set at $850^{\circ} \mathrm{C}$ and in the reduction zone the temperature was $500{ }^{\circ} \mathrm{C}$. Cystine was used as an analytical standard. For each analyzed sample, two determinations were performed, using different amounts from the sample $(\sim 1.5 \mathrm{mg}$ and $\sim 2.5 \mathrm{mg})$. The result was calculated as the average of the two determinations.

\subsection{Physicochemical Characterization of the Obtained Calcium Lactate}

Fourier Transform Infrared spectra (FTIR) were performed in solid phase using a JASCO FT/IR-4200 spectrophotometer equipped with an ATR PRO450-S accessory with diamond optics, working in the attenuated total reflection (ATR) technique in the spectral range of $400-4000 \mathrm{~cm}^{-1}$, at a resolution of $4 \mathrm{~cm}^{-1}$.

$\mathrm{X}$-ray diffraction (XRD) experiments were performed on powders, using a Rigaku Ultima IV diffractometer in parallel beam geometry equipped with $\mathrm{CuK} \alpha$ radiation (wavelength $1.5406 \AA$ ). The XRD patterns were collected in the $2 \theta$ range between 10 and 70 with a speed of $2^{\circ} / \mathrm{min}$ and a step size of $0.02^{\circ}$. PDXL software from Rigaku, connected to the ICDD database was used for phase identification and XRD patterns refinement using the Whole Pattern Powder Fitting (WPPF) method (Rigaku's PDXL software).

Thermal measurements were performed on a Mettler Toledo TGA/SDTA 851e thermal analyzer apparatus, in an airflow atmosphere with a flow rate of $80 \mathrm{~mL} \mathrm{~min}^{-1}$ and at a heating rate of $10 \mathrm{~K} \mathrm{~min}^{-1}$. The TG curves were recorded from room temperature to $1000{ }^{\circ} \mathrm{C}$. The samples were held in alumina crucibles.

\subsection{Calcium Lactate Pharmacotechnical Properties}

The determined pharmacotehnical characteristics were:

(i) Moisture content, which is important to be reduced in all powders included in solid dosage forms, was assessed as the loss on drying, by the Karl Fisher method using a HR 73 Mettler Toledo halogen humidity analyzer.

(ii) Particle size is highly influencing the behavior of the powder during the manufacturing process, as well as the dissolution profile of the final pharmaceutical form. The sieving and sorting method were applied, using a CISA Sieve Shaker Mod. RP 10, produced by Cisa Cedaceria Industrial, Spain. The powder was passed, under mechanical shaking through a set of sieves with well-known mesh sizes, placed under each other, in ascending order of the finesse degree.

(iii) Flowability, a demanding mechanical characteristic for direct compression technology, was established by the angle of repose, flowing time and rate parameters, registered for $60 \mathrm{~g}$ of powder that flows through a standardized diameter nozzle. The study was performed with an Automated Powder and Granulate Testing System PTG-S3, manufactured by Pharma Test Apparatebau GmbH, Germany.

(iv) Compressibility, also a critical property for the manufacturing method, was settled by determining volumetric characteristics (bulk and tapped density) and by calculating the Hausner ratio (HR) and Carr Index (CI), also used for flowability predictions. Vankel Tap Density Tester, produced by Vankel Industries Inc., Palo Alto, CA, USA, was used. First, the bulk density was determined by measuring the volume of $50 \mathrm{~g}$ of powder into a graduated cylinder. The tapped volume was measured after applying a different number of mechanical shocks, then the Hausner ratio (HR) was calculated as the ratio between tapped and bulk density. A value under 1.25 was an indication that the powder was free flowing. Carr index is given by the following equation: 


$$
C I \%=\frac{(\text { tapped density }- \text { bulk density }) \times 100}{\text { tapped density }}
$$

According to literature data, better flowability and compressibility can be obtained if the value of the Carr Index is smaller [50-54].

All tests were performed six times for each powder.

\subsection{Tablets Preformulation Studies}

\subsubsection{Excipient Selection}

For developing an optimum pharmaceutical form, preformulation studies on the direct compression material must be performed. The final DC powder must have adequate mechanical characteristics. In this context, considering that the active ingredient dosage is $342.105 \mathrm{mg} /$ tablet, the excipients must be carefully selected and efficient in low quantities, as it is not compliant to manufacture high weight tablets. The two active ingredients proved to have different pharmacotechnical characteristics, so it cannot use the same excipients, because they need to meet the individual requirements of the base powder.

For mussels calcium lactate the following were selected: (i) Microcrystalline cellulose 302 - a filler excipient with great binding attributes and the best choice to improve active ingredient's flowability, (ii) Sodium Starch Glycolate, the sodium salt of cross-linked carboxymethyl starch, chosen for its superdisintegrant properties through rapid swelling due to the adsorption of large amounts of water leading to faster disintegration, also having good flow abilities, not characteristic for superdisintegrants excipients, and (iii) magnesium stearate as lubricant.

As excipients for PURACAL ${ }^{\circledR}$, maize starch, a filler and disintegrant excipient suitable for the active ingredients which contain a high amount of moisture and to enhance the blend compressibility were chosen. Its low flowability was the reason for which the two lubricants (magnesium stearate and talc) were added [55-57].

\subsubsection{Preparation of Direct Compression Powders}

The active ingredients (mussels calcium lactate and DC calcium lactate) were mixed with the direct compression excipients in the following ratios: F1-mussels calcium lactate:Microcrystalline cellulose 302:Sodium Starch Glycolate:Magnesium stearate 62.2:35.8:1:1 and F2-PURACAL ${ }^{\circledR}$ :Maize Starch:Magnesium stearate:Talc 62.2:34.8:1:2.

The raw materials were accurately weighed.

F1-calcium lactate from mussels, Sodium Starch Glycolate and Microcrystalline cellulose 302 were passed through a 20-mesh sieve, then were mixed and homogenized in $\mathrm{V}$ blender for $15 \mathrm{~min}$ at $15 \mathrm{rpm}$, at room temperature. Over blend, the Magnesium Stearate sifted on 40-mesh sieve was added and lubricated for $5 \mathrm{~min}$.

F2-PURACAL ${ }^{\circledR}$ and Maize Starch were similarly mixed for $15 \mathrm{~min}$, then the lubricants were added.

\subsubsection{Precompression Studies for Tablets Containing Calcium Lactate}

Both obtained direct compression blends were subjected to the same pharmacotechnical studies as the active ingredients, being tested for: moisture content, particle dimensions, flowing and compression abilities, using the same methods already described. All tests were performed six times for each composed powder.

\subsection{Formulation of the Immediate Release Tablets Containing Calcium Lactate}

After determining the characteristics of the powder, the final formulations of the tablets were established as they are listed in Table 6. 
Table 6. The formulations for the calcium lactate tablet.

\begin{tabular}{|c|c|c|c|}
\hline \multirow{2}{*}{ Ingredient } & \multicolumn{2}{|c|}{ Quantity mg/Tablet } & \multirow{2}{*}{ Role in Formulation } \\
\hline & F1 & F2 & \\
\hline Calcium lactate from mussel shells & 342.10 & - & Active ingredient \\
\hline Calcium lactate DC (PURACAL ${ }^{\circledR}$ ) & - & 342.10 & Active ingredient \\
\hline Microcrystalline cellulose 302 & 196.90 & - & $\begin{array}{l}\text { Filler } \\
\text { Binder }\end{array}$ \\
\hline Sodium Starch Glycolate & 5.50 & - & Superdisintegrant \\
\hline Maize Starch & - & 191.40 & $\begin{array}{c}\text { Filler } \\
\text { Disintegrant }\end{array}$ \\
\hline Magnesium stearate & 5.50 & 5.50 & Lubricant \\
\hline Talc & - & 11.00 & Lubricant \\
\hline TOTAL & 550 & 550 & \\
\hline
\end{tabular}

\subsection{Tablets Manufacturing}

For the immediate release tablets manufacturing, direct compression technology was selected. A single-post eccentric machine Korsch EK-O type, equipped with $12 \mathrm{~mm}$ flat punches, adjusted to the target weight of tablets $(550 \mathrm{mg})$, was used. The applied compression force was low $(8-9 \mathrm{kN})$.

\subsection{Quality Parameters of the Tablets}

After manufacturing, the obtained tablets were tested to determine the quality characteristics of the final products, according to compendial specifications and in force regulations $[58,59]$.

\subsubsection{Sizes (Diameter and Thickness)}

The uniformity of the tablets' diameter and thickness depend on the compressed material homogeneity and density or on the right compression force. The dimensions were determined on ten tablets of each formulation with VK 200 Tablet Hardness Tester, produced by Vanderkamp, Cary, NC, USA.

\subsubsection{Mass Uniformity}

The weight variation is also influenced by the compression parameters. The analysis was done according to European Pharmacopoeia, by individually weighing 30 tablets of each formulation, then calculating the average mass. The tablets are complying with the test if no more than 1 individual mass is outside the limits of $85-115 \%$ of the average mass [60].

\subsubsection{Mechanical Resistance}

The tablets must be sufficiently cohesive to maintain their integrity during handling, packaging, transport and handling. The tablet crushing strength cannot exceed certain limits as it would compromise the disintegrating properties, the release of the active ingredients and even the effectiveness of the product. Tablet hardness was measured on 10 tablets of each formulation, with VK 200 Tablet Hardness Tester. Each tablet was placed on the measuring plate, the mobile part moves at a low speed until the tablet breaks and the load required to crush the tablet is registered.

\subsubsection{Friability}

Friability is the resistance to abrasion and rolling of a tablet subjected to external forces. The initial weight of 10 tablets was measured and they were placed in the Vankel friabilator, rotating at $25 \mathrm{rpm}$ for $4 \mathrm{~min}$, then weighed again. The difference in the weight was noted and was expressed as a percentage. It should be preferably below $1.0 \%$. 


\subsubsection{In-Vitro Disintegration Time}

A crucial condition for the absorption of the active ingredients from the tablets is their disintegration into primary particles, at a suitable time when they are brought into an aqueous medium. According to European Pharmacopoeia, immediate release tablets must disintegrate in water, at $37 \pm 0.5^{\circ} \mathrm{C}$, for a maximum of $15 \mathrm{~min}$. The determination was performed using Erweka DT 3 apparatus, manufactured by Erweka ${ }^{\circledR} \mathrm{GmbH}$, Langen (Hessen), Hessen, Germany. The test was carried out on six tablets of each formulation using distilled water at $37 \pm 0.5^{\circ} \mathrm{C}$ as a disintegration media. The time taken for complete disintegration of the tablet, with no residue left on the screen, was measured in seconds [60].

\subsubsection{In-Vitro Dissolution Rate}

The dissolution rate was determined using USP basket Apparatus I (dissolution tester ERWEKA DT 800), in $500 \mathrm{~mL}$ of distilled water. The apparatus was settled at $37 \pm 0.5^{\circ} \mathrm{C}$, with a rotating speed of $100 \mathrm{rpm}$ and the test was performed on 6 tablets of each formulation. The amount of dissolved calcium lactate was determined after $30 \mathrm{~min}$, by the titrimetric method. After $30 \mathrm{~min}, 300 \mathrm{~mL}$ of each vat were filtered. To $100 \mathrm{~mL}$ of filtered solution, $150 \mathrm{~mL}$ of water, $2 \mathrm{~mL}$ of $3 \mathrm{~N}$ hydrochloric acid and $15 \mathrm{~mL}$ of $1 \mathrm{~N}$ sodium hydroxide were added and stirred. $300 \mathrm{mg}$ of blue hydroxynaphthol were added and titrated with $0.05 \mathrm{M}$ edetate disodium solution to blue [61].

\section{Conclusions}

New manufactured tablets containing Black Sea mussel shell calcium lactate have been formulated. The elemental analysis indicates that the obtained powder contains a higher amount of calcium lactate with small quantities of calcium nitrate. Analysis of physical and chemical properties of synthesized calcium lactate using spectral and thermal analysis methods was performed. The FTIR, XRD and thermal TG-DTG-DTA analyses confirmed the formation of calcium lactate, with no influence of the low nitrogen content. The determined pharmacotechnical properties of the calcium lactate synthesized from mussel shells proved its efficiency for use in the tablet formulation. For assessing the good performance quality of byproduct calcium lactate tablets (F1) a comparison with another already direct compressible calcium lactate PURACAL ${ }^{\circledR}(\mathrm{F} 2)$ was achieved. The results of the quality test performed on both formulations are proving that in the present study high quality calcium lactate tablets were manufactured. Both formulations pharmacotechnical and in vitro properties were satisfactory and within the limits imposed by rules into force. As the results are similar for F1 and F2, it can be concluded that the physical and mechanical properties of the tablets are not influenced by the type of calcium lactate used. The calcium lactate obtained from Black Sea mussel shells is a strong candidate for the pharmaceutical industry, as it is eco-friendly, not expensive, easy to synthetize, has excellent pharmacotechnical properties and leads to superior quality drug delivery systems.

Author Contributions: Conceptualization, M.M., E.M. and E.A.O.; methodology, M.M., A.C.N., A.A.S. and T.D.B.; formal analysis, M.M., A.C.N., G.M.N. and T.D.B.; investigation, I.A., J.P.C., G.M.N., I.S. and T.D.B.; data curation, M.M. and A.M.M.; writing-original draft preparation, E.A.O. and A.M.M.; writing-review and editing, E.A.O. and A.M.M.; All authors have read and agreed to the published version of the manuscript.

Funding: This research received no external funding. The APC was funded by the Carol Davila University of Medicine and Pharmacy.

Institutional Review Board Statement: Not applicable.

Conflicts of Interest: The authors declare no conflict of interest. 


\section{References}

1. Murphy, J.N.; Hawboldt, K.; Kerton, F.M. Enzymatic processing of mussel shells to produce biorenewable calcium carbonate in seawater. Green Chem. 2018, 20, 2913-2920. [CrossRef]

2. Arvanitoyannis, I.S.; Kassaveti, A. Fish industry waste: Treatments, environmental impacts, current and potential uses. Int. J. Food Sci. Technol. 2008, 43, 726-745. [CrossRef]

3. Kerton, F.M.; Liu, Y.; Omari, K.W.; Hawboldt, K. Green chemistry and the oceanbased biorefinery. Green Chem. $2013,15,860-871$. [CrossRef]

4. Kerton, F.M. Chemical Process Technology for a Sustainable Future; Letcher, T.M., Scott, J.L., Paterson, D.A., Eds.; Royal Society of Chemistry Publishing: Cambridge, UK, 2014.

5. Yan, N.; Chen, X. Sustainability: Don't waste seafood waste. Nature 2015, 524, 155-157. [CrossRef]

6. Kerton, F.M.; Yan, N. Fuels, Chemicals and Materials from the Oceans and Aquatic Sources; Wiley: Chichester, UK, 2017.

7. Wells-Berlin, A.M.; Perry, M.C.; Kohn, R.A.; Paynter, K.T., Jr.; Ottinger, M.A. Composition, Shell Strength, and Metabolizable Energy of Mulinia lateralis and Ischadium recurvum as Food for Wintering Surf Scoters (Melanitta perspicillata). PLoS ONE 2015, 10, e0119839. [CrossRef]

8. Sturm, C.F.; Pearce, T.A.; Valdes, A. The Mollusks: A Guide to Their Study, Collection, and Preservation; American Malacological Society: Pittsburgh, PA, USA, 2006.

9. Available online: https://www.fao.org/state-of-fisheries-aquaculture (accessed on 30 November 2021).

10. Smaal, A.C.; Ferreira, J.G.; Grant, J.; Petersen, J.K.; Strand, Ø. Goods and Services of Marine Bivalves; Springer International Publishing: Berlin/Heidelberg, Germany, 2018. [CrossRef]

11. Shumway, S.E. Shellfish Aquaculture and the Environment; Wiley-Blackwell: Ames, IA, USA, 2011. [CrossRef]

12. Barros, M.C.; Bello, P.M.; Bao, M.; Torrado, J.J. From waste to commodity: Transforming shells into high purity calcium carbonate. J. Clean. Prod. 2009, 17, 400-407. [CrossRef]

13. Tekin, K. Hydrothermal conversion of russian olive seeds into crude bio-oil using a CaO catalyst derived from waste mussel shells. Energy Fuels 2015, 29, 4382-4392. [CrossRef]

14. Scialla, S.; Carella, F.; Dapporto, M.; Sprio, S.; Piancastelli, A.; Palazzo, B.; Adamiano, A.; Degli Esposti, L.; Iafisco, M.; Piccirillo, C. Mussel Shell-Derived Macroporous 3D Scaffold: Characterization and Optimization Study of a Bioceramic from the Circular Economy. Mar. Drugs 2020, 18, 309. [CrossRef]

15. Lee, Y.-K.; Kim, S.-D. Preparation and characteristics of calcium lactate from Black Snail. Nutraceuticals Food 2003, 8, 166-172. [CrossRef]

16. Allen, L.H. Calcium bioavailability and absorption. Am. J. Clin. Nutr. 1982, 35, 738-808. [CrossRef]

17. Lee, G.K.; Kim, Y.M.; Min, Y.C. The production of calcium lactate by Lactobacilus sporogenes II. Production of calcium lactate. Korean J. Food Nutr. 1988, 1, 102-107.

18. Shelef, L.A. Antimicrobial effects of lactates: A review. J. Food Prot. 1994, 57, 415-445. [CrossRef]

19. Wargovich, M.; Allnutt, D.; Palmer, C.; Anaya, P.; Stephens, L.C. Inhibition of the promotional phase of azohymethane-induced colon carcinogenesis in the F344 rat by calcium lactate: Effect of simulating two human nutrient density lecels. Cancer Lett. 1990, 53, 17-25. [CrossRef]

20. Mititelu, M.; Ioniţă, A.C.; Moroşan, E. Research regarding integral processing of mussels from Black Sea. Farmacia 2014, 62, 625-632.

21. Petibois, C.; Melin, A.-M.; Perromat, A.; Cazorla, G.; Déléris, G. Glucose and lactate concentration determination on single microsamples by Fourier-transform infrared spectroscopy. J. Lab. Clin. Med. 2000, 135, 210-215. [CrossRef] [PubMed]

22. Hwang, T.I.; Kima, J.I.; Joshi, M.K.; Park, C.H.; Kim, C.S. Simultaneous regeneration of calcium lactate and cellulose into PCL nanofiber for biomedical application. Carbohydr. Polym. Vol. 2019, 212, 21-29. [CrossRef]

23. Tansman, G.F.; Kindstedt, P.S.; Hughes, J.M. Powder X-ray diffraction can differentiate between enantiometric variants of calcium lactate pentahydrate crystal in cheese. J. Dairy Sci. 2014, 97, 7354-7362. [CrossRef] [PubMed]

24. Shaheen, N.; Jalil, A.; Adnan, F.; Khushnood, R.A. Isolation of alkaliphilic calcifying bacteria and their feasibility for enhanced $\mathrm{CaCO}_{3}$ precipitation in bio-based cementitious composites. Microb. Biotechnol. 2021, 14, 1044-1059. [CrossRef] [PubMed]

25. Sakata, Y.; Shiraishi, S.; Otsuka, M. Characterization of dehydration and hydration behavior of calcium lactate pentahydrate and its anhydrate. Colloids Surf. B Biointerfaces 2005, 46, 135-141. [CrossRef]

26. Zhou, X.; Nauka, E.; Narang, A.; Mao, C. Flow Function of Pharmaceutical Powders at Low-Stress Conditions Can Be Inferred Using a Simple Flow-through-Orifice Device. J. Pharm. Sci. 2020, 109, 2009-2017. [CrossRef]

27. Nalluri, V.R.; Kuentz, M. Flowability Characterisation of Drug-Excipient Blends Using a Novel Powder Avalanching Method. Eur. J. Pharm. Biopharm. 2010, 74, 388-396. [CrossRef] [PubMed]

28. Peddapatla, R.V.G.; Sheridan, G.; Slevin, C.; Swaminathan, S.; Browning, I.; O'Reilly, C.; Worku, Z.A.; Egan, D.; Sheehan, S.; Crean, A.M. Process Model Approach to Predict Tablet Weight Variability for Direct Compression Formulations at Pilot and Production Scale. Pharmaceutics 2021, 13, 1033. [CrossRef]

29. Rantanen, J.; Khinast, J. The Future of Pharmaceutical Manufacturing Sciences. J. Pharm. Sci. 2015, 104, 3612-3638. [CrossRef] [PubMed]

30. Razavi, S.M.; Scicolone, J.; Snee, R.D.; Kumar, A.; Bertels, J.; Cappuyns, P.; Van Assche, I.; Cuitiño, A.M.; Muzzio, F. Prediction of tablet weight variability in continuous manufacturing. Int. J. Pharm. 2020, 575, 118727. [CrossRef] 
31. Partheniadis, I.; Zarafidou, E.; Litinas, K.E.; Nikolakakis, I. Enteric Release Essential Oil Prepared by Co-Spray Drying Methacrylate/Polysaccharides-Influence of Starch Type. Pharmaceutics 2020, 12, 571. [CrossRef] [PubMed]

32. Elversson, J.; Millqvist-Fureby, A. Particle size and density in spray drying-Effects of carbohydrate properties. J. Pharm. Sci. 2005, 94, 2049-2060. [CrossRef] [PubMed]

33. Montgomery, D.C. Design and Analysis of Experiments, 8th ed.; John and Wiley and Sons: New York, NY, USA, 2013.

34. Aulton, M.E.; Taylor, K. Aulton's Pharmaceutics: The Design and Manufacture of Medicines; Churchill Livingstone/Elsevier: Amsterdam, The Netherlands, 2013; p. 196.

35. Xie, S.X.; Liu, Q.; Cui, S.W. Starch modification and applications. In Food Carbohydrates: Chemistry, Physical Properties, and Applications; Cui, S.W., Ed.; CRC Press: Boca Raton, FL, USA, 2005; pp. 357-405.

36. Abd Maurad, Z.; Abdullah, L.C.; Anuar, M.S.; Abdul Karim Shah, N.N.; Idris, Z. Preparation, Characterization, Morphological and Particle Properties of Crystallized Palm-Based Methyl Ester Sulphonates (MES) Powder. Molecules 2020, 25, 2629. [CrossRef]

37. Farquharson, A.; Gladding, Z.; Ritchie, G.; Shende, C.; Cosgrove, J.; Smith, W.; Brouillette, C.; Farquharson, S. Drug Content Uniformity: Quantifying Loratadine in Tablets Using a Created Raman Excipient Spectrum. Pharmaceutics 2021, 13, 309. [CrossRef]

38. Shadangi, M.; Seth, S.; Senapati, D. Critical roles of magnesium stearate in formulation development of a highly soluble drug metformin hyrochloride. Int. J. Pharm. Sci. Res. 2012, 3, 1188-1193.

39. Ghosh, B.; Ray, S.; Das, M. Formulation, development and optimization of mouth dissolving tablets of Rizatriptan benzoate. J. Pharm. Investig. 2015, 45, 593-600. [CrossRef]

40. Mostafa, H.F.; Ibrahim, M.A.; Sakr, A. Development and optimization of dextromethorphan hydrobromide oral disintegrating tablets: Effect of formulation and process variables. Pharm. Dev. Technol. 2013, 18, 454-463. [CrossRef]

41. Gowda, V.; Pabari, R.M.; Kelly, J.G.; Ramtoola, Z. Influence of Prosolv and Prosolv: Mannitol 200 direct compression fillers on the physicomechanical properties of atorvastatin oral dispersible tablets. Pharm. Dev. Technol. 2015, 20, 394-400. [CrossRef] [PubMed]

42. Ciolan, D.F.; Mînea, A.; Andrieș, A.; Nicoară, A.C.; Rădulescu, F.S.; Miron, D.S. The influence of compendial cells design and experimental setup on the in-vitro similarity of ketoconazole topical creams. Farmacia 2015, 63, 865-871.

43. Soulairol, I.; Sanchez-Ballester, N.M.; Aubert, A.; Tarlier, N.; Bataille, B.; Quignard, F.; Sharkawi, T. Evaluation of the Super Disintegrant Functionnalities of Alginic Acid and Calcium Alginate for the Design of Orodispersible Mini Tablets. Carb. Polym. 2018, 197, 576-585. [CrossRef] [PubMed]

44. Popescu, I.A.; Donea, C.; Lupulesa, D.; Nicoară, A.C.; Popa, D.E.; Miron, D.S.; Rădulescu, F.S. Comparative assesment of the in vitro performance for modified release tablets containing pentoxifylline using padlle method and flow-through cells. Farmacia 2015, 63, 903-908

45. Grignard, E.; Taylor, R.; McAllister, M.; Box, K.; Fotaki, N. Considerations for the development of in vitro dissolution tests to reduce or replace preclinical oral absorption studies. Eur. J. Pharm. Sci. 2017, 99, 193-201. [CrossRef] [PubMed]

46. Litou, C.; Vertzoni, M.; Goumas, C.; Vasdekis, V.; Xu, W.; Kesisoglou, F.; Reppas, C. Characteristics of the human upper gastrointestinal contents in the fasted state under hypo- and a-chlorhydric gastric conditions under conditions of typical drug-Drug interaction studies. Pharm. Res. 2016, 33, 1399-1412. [CrossRef]

47. Manescu, O.; Lupuleasa, D.; Miron, D.S.; Budura, E.A.; Radulescu, F.S. In vitro drug release from topical antifungal pharmaceutical formulations. Farmacia 2011, 59, 15-23.

48. Nicoară, A.C.; Cazacincu, R.G.; Lupuleasa, D.; Miron, D.S.; Rădulescu, F.S. Formulation and in-vitro release testing of rectal suppositories containing nimesulide. Farmacia 2015, 63, 111-117.

49. Costa, P.; Sousa Lobo, J.M. Modeling and comparison of dissolution profiles. Eur. J. Pharm. Sci. 2001, 13, 123-133. [CrossRef]

50. Mitu, M.A.; Cretu, E.A.; Novac, M.; Karampelas, O.; Nicoara, A.; Nitulescu, G.; Lupuleasa, D. The Flowing Characteristics of Some Composed Powders Containing Inclusion Complexes in Beta-Cyclodextrin. In 21st Century Pharmacy-between Intelligent Specialization and Social Responsibility 2018, Proceedings of the Romanian National Congress of Pharmacy, Bucharest, Romania, 26-29 September 2018, 17th ed.; Draganescu, D., Arsene, A., Eds.; Carol Davila University of Medicine and Pharmacy: Bucharest, Romania, 2018; pp. 129-133.

51. Balaci, T.; Velescu, B.; Karampelas, O.; Musuc, A.M.; Nitulescu, G.M.; Ozon, E.A.; Nitulescu, G.; Gird, C.E.; Fita, C.; Lupuliasa, D. Physico-Chemical and Pharmaco-Technical Characterization of Inclusion Complexes Formed by Rutoside with beta-Cyclodextrin and Hydroxypropyl-beta-Cyclodextrin Used to Develop Solid Dosage Forms. Processes 2021, 9, 26. [CrossRef]

52. Leaper, M.C. Measuring the Flow Functions of Pharmaceutical Powders Using the Brookfield Powder Flow Tester and Freeman FT4. Processes 2021, 9, 2032. [CrossRef]

53. Janssen, P.H.M.; Depaifve, S.; Neveu, A.; Francqui, F.; Dickhoff, B.H.J. Impact of Powder Properties on the Rheological Behavior of Excipients. Pharmaceutics 2021, 13, 1198. [CrossRef] [PubMed]

54. Saker, A.; Cares-Pacheco, M.G.; Marchal, P.; Falk, V. Powders Flowability Assessment in Granular Compaction: What about the Consistency of Hausner Ratio? Powder Technol. 2019, 354, 52-63. [CrossRef]

55. Saramet, G.; Rădulescu, F.Ș.; Bărbuceanu, S.F.; Miron, D.S.; Fița, C.A.; Mitu, M.A.; Stănescu, A.A.; Lupuliasa, D. Influence of some formulation factors on the release of phenytoin sodium from hydrophilic matrix tablets. Farmacia 2014, 62, $1230-1238$.

56. Madzarevic, M.; Medarevic, D.; Vulovic, A.; Sustersic, T.; Djuris, J.; Filipovic, N.; Ibric, S. Optimization and Prediction of Ibuprofen Release from 3D DLP Printlets Using Artificial Neural Networks. Pharmaceutics 2019, 11, 544. [CrossRef]

57. Rowe, R.C.; Sheskey, P.J.; Willer, P.J. Handbook of Pharmaceutical Excipients; RPS: London, UK, 2009; pp. 651-653. 
58. Musuc, A.M.; Anuta, V.; Atkinson, I.; Popa, V.T.; Sarbu, I.; Mircioiu, C.; Abdalrb, G.A.; Mitu, M.A.; Ozon, E.A. Development and Characterization of Orally Disintegrating Tablets Containing a Captopril-Cyclodextrin Complex. Pharmaceutics 2020, $12,744$. [CrossRef]

59. Lu, B. New Techniques and New Doasge. Forms of Drugs; People's Medical Publishing House: Beijing, China, 2005; pp. 386-388.

60. Council of Europe. European Pharmacopoeia, 10th ed.; EDQM, Council of Europe: Strasbourg, France, 2019.

61. USP. The United States Pharmacopeia 32-The National Formulary 27; The United States Pharmacopeial Convention, Inc.: Rockville, MD, USA, 2009. 